\title{
Lusotopie
}

Recherches politiques internationales sur les espaces

issus de l'histoire et de la colonisation portugaises

$\operatorname{XIV}(1) \mid 2007$

Islam en lusophonie

\section{Roots of Diversity in Mozambican Islam}

Raizes de diversidade no Islão moçambicano

Les racines de la diversité dans l'Islam du Mozambique

Liazzat J. K. Bonate

\section{(2) OpenEdition}

\section{Journals}

Electronic version

URL: https://journals.openedition.org/lusotopie/1074

ISSN: 1768-3084

\section{Publisher}

Idemec - UMR 7307

Printed version

Date of publication: 30 June 2007

Number of pages: 129-149

ISSN: 1257-0273

Electronic reference

Liazzat J. K. Bonate, "Roots of Diversity in Mozambican Islam", Lusotopie [Online], XIV(1) | 2007, Online since 30 March 2016, connection on 10 December 2021. URL: http://journals.openedition.org/

lusotopie/1074 


\section{ROOTS OF DIVERSITY IN MOZAMBIGAN ISLAM}

This paper explores historical roots for the existing diversity of the conceptions of Islam among African Sunni Muslims of Mozambique. This diversity is frequently expressed by internal Muslim debates and competitions centred on the nature of Islamic authority and on the definition of 'orthodoxy.' After identifying roughly three divergent conceptions of Islamic authority and ritual among Mozambican Muslims, the author analyses specific historical contexts within which each of these conceptions of Islam emerged and confronted one another. In particular, the paper focuses on changes with respect to religious authority and ritual. One of the central arguments of this paper is that on the emergence of each new conception, local Muslims set upon redefining what constituted the centre and the margin of Islam in Mozambique, but despite the attempts to the contrary, the old conceptions have persisted and continuously posed challenges to the newly-established centre.

\section{Raizes de diversidade no Islão moçambicano}

Este artigo explora as razões históricas para a existência das diversas concepções do Islão entre os muçulmanos sunnitas africanos de Moçambique. A diversidade de concepções é expressa através de debates e competições internos entre os muçulmanos em torno de natureza da autoridade islâmica e da definição de "ortodoxia" islâmica. Após ter identificado três concepções divergentes, a autora analisa contextos históricos específicos nos quais cada uma destas emergiu e confrontou as outras concepções. $\mathrm{O}$ artigo foca em particular as mudanças da autoridade religiosa e dos ritos. Um dos argumentos centrais de artigo é que com a emergência de cada uma das novas concepções, os muçulmanos locais se envolverem na definição do centro e da margem do Islão. No entanto, apesar de esforços de elimina-los, as concepções anteriores não desapareceram e continuaram desafiando os novos centros do Islão a partir de margens a que foram supostamente relegados.

\section{Les racines de la diversité dans l'islam du Mozambique}

Cet article explore les racines historiques de la diversité existant actuellement dans les conceptions de l'islam parmi les musulmans sunnites africains du Mozambique. Cette diversité s'exprime souvent par des discussions et des rivalités musulmanes internes, centrées sur la nature de l'autorité islamique et sur la définition de l'« orthodoxie ». Après avoir identifié en gros trois conceptions divergentes de l'autorité et du rituel islamique parmi les musulmans du Mozambique, l'auteur analyse les contextes historiques spécifiques au sein desquels chacune de ces conceptions de l'islam a émergé et fait face aux autres. Plus particulièrement, l'article se concentre sur les changements concernant l'autorité religieuse et le rituel. L'un des arguments principaux de cet article est que, face à l'émergence de chaque nouvelle conception, les musulmans locaux ont entrepris de redéfinir ce qui constituait le centre et la marge de l'islam au Mozambique, mais malgré les tentatives dans l'autre sens, les anciennes conceptions ont persisté et représenté des défis continuels pour le centre nouvellement établi. 
$\mathrm{I}_{\mathrm{T}}^{\mathrm{n}}$ n contemporary Mozambique, as elsewhere, the conceptions of Islam are diverse. This diversity is often expressed by internal Muslim debate about the nature of Islamic authority and the definition of "orthodoxy", in particular with regard to religious rituals. Individual Muslims acknowledge those people as holding a legitimate Islamic authority whose claims and views are perceived to be in line with an Islamic "orthodoxy". "Orthodoxy", i.e. perceived "truthfulness" and "correctness" of doctrine and rituals, however, is in "the eyes of beholder", and in Mozambique, as elsewhere, it is not something clearly established but rather a point of contention between different groups, each of whom claims authority over its definitions. Islam in Mozambique is centred on the politics of "sacred authority" involving "competition and contest over interpretation of the symbols and the control of the institutions"'.

This paper focuses on the diversity of the conceptions of Islam among African Sunni Muslims ${ }^{4}$, and is based on fieldwork in Angoche, Mozambique Island and Maputo city, as well as on archival and various other primary and secondary

Both colonial and post-colonial literatures on Islam in Mozambique have tended to uphold monolithic Orientalist views and assess local beliefs and practices against those held in Muslim "heartlands in Arabia" and perceived universal and immutable "orthodoxy". The sources highlight "unorthodox" character of Islam practiced in Mozambique, believed to represent a "syncretism" of African "traditions" and "customs" with "proper" Islam. See, E.C. LuPI, Angoche. Breve memória sobre uma das Capitanias-Môres do Distrito de Moçambique, Lisbon, Typografia do Annuario Commercial, 1907: 145, 154-157; 163, 169-170, 176-177; P.M. Амовім, Relatório sobre a ocupação de Angoche: operações de campanha e mais serviço realizados, anno 1910, Lourenço Marques, Imprensa Nacional, 1911: 98, 102, 115-116; J. de Azevedo Coutinho, As duas conquistas de Angoche, Lisbon, Pelo Império, 11, 1935: 9; J. A. Gomes de Melo Branquinho, "Relatório da Prospecção ao Distrito de Moçambique (Um estudo de estruturas hierárquicas tradicionais e religiosas, e da sua situação político-social)", Nampula, 22 April 1969; F. da Costa Freire, Prospecção das Forças Tradicionais - Distrito de Moçambique, Província de Moçambique, SCCI, Secreto, Arquivo Histórico de Moçambique, Maputo, Secção Especial n 20, Cotas S.E., 2 III P 6, Portugal, Lourenço Marques, 30 December, 1969: 331; A.J. de Mello Machado, Entre os macuas de Angoche: Historiando Moçambique, Lisbon, Prelo, 1970: 181, 191-192; J. Capela \& E. Medeiros, O tráfico de escravos em Moçambique para as Ilhas do Indico, 1720-1902, Maputo, Eduardo Mondlane University, 1987: 111-113; M.I. CAsas, et al., Gender Profile of Nampula Province. Final Report, Embassy of the Kingdom of the Netherlands, Maputo - Nampula, October 1998: 95.

2 See A. BAng, "Islamic Reform in East Africa, ca. 1870-1925: The Alawi Case", Paper presented at the workshop "Reasserting Connections, Commonalties, and Cosmopolitanism: The Western Indian Ocean since 1800", Yale University, November 3-5, 2000, 32 p.: 28.

${ }^{3}$ D.F. Eickelman \& J. Piscatori, Muslim Politics, Princeton (NJ), Princeton University Press, 1996: 5, 46-80.

${ }^{4}$ The religious controversies exposed, however, especially those involving Sufi versus Islamist divide, have affected all Sunni Muslims, be them locals or descending from the Comoro Islands or the Indian Sub-Continent, and the followers of both sides are spread from north to south of the country. Contrary to what Éric Morier-Genoud argues, this divide has no geographic, ethnic or racial boundaries. Historically, the Indian associations of the Comunidades Mohametana or Muçulmanas maintained Sufi rites, celebrated mawlides and sponsored their African brethren by donating mosques and financing their annual mawlid processions, which continue to take place annually up to the present day. See É. Morier-Genoud, "L'islam au Mozambique après l'indépendance: histoire d'une montée en puissance", L'Afrique politique (Paris), 2002: 126. 
sources. During fieldwork, roughly three groups could be discerned, each representing a particular conception of Islam. First one included people following regional historical Swahili conception of Islam; second group consisted of the members of Shadhiliyya Yashrutiyya and Qadiriyya Sufi Orders (t/dikiri in local vernacular; Ar., sing., tariqa, and pl. turuq); and the third group was comprised of 'modernist' Islamists, also known as the Wahhabi ${ }^{5}$.

Similar to Robert Launay's approach to the Koko community of Côte d'Ivoire ${ }^{6}$, this paper focuses on how different conceptions of Islam emerged and confronted one another within specific historical contexts. The paper addresses changes with respect to religious authority and ritual following the appearance of each of the conceptions, when Muslims set upon redefining what constituted locally the centre and the margin of Islam. As Rosander points out,

" 'margins' $[. .$.$] indicate being morally inferior or 'second-rate' in relation to the cen-$ tre, even if the distance in space or time may be none. The centre constitutes the normative and established setting, seen in relation to the margins, which represents those who are not fully recognized, with an aberrant behavior or hidden agendas. The margins lack the legitimacy of the centre, which dominated the ideological discourse and the interpretation of social practice."

But the old conceptions and rituals were not eliminated completely despite attempts to marginalize them. In fact, they have persisted up today, each representing a layer of changes, transformations and confrontation in Mozambican Muslim history. As with Launay, this essay does not intend to write a historical account in conventional chronological order, but rather explores "the themes of change and of confrontation between different conceptions of Islam".

\section{Swahili Islam and Islamic Authority}

On their arrival in the 16th century, the Portuguese noted that northern and central Mozambican coastal regions shared Swahili identity and culture with their neigbours to the north and were firmly established within Swahili economic networks ${ }^{9}$. Islam thus was conceived along regional Swahili tradition, which incorporated African coastal culture and the influences of the Western Indian Ocean regions, such as of Hadramawt. They were constructed in ways as to maintain the legitimacy of the Swahili clans over the coastal territory against possible

The boundaries between these groups appear sometimes to be fuzzy, especially in the case of "African Islam" and Sufis, nevertheless this division seems to be roughly corresponding to three different conceptions of Islamic authority and ritual in Mozambique.

${ }^{6}$ R. Launay, Beyond the Stream: Islam and Society in a West African Town, Berkeley, University of California Press, 1992: 13-14, <http://ark.cdlib.org/ark:/13030/ft3199n7w5>.

E. Evers Rosander, "Introduction: The Islamization of 'Tradition' and 'Modernity'”, in E.E. Rosander \& D. Westerland, eds, African Islam and Islam in Africa: Encounters between Sufis and Islamists, London, Hurst and $\mathrm{C}^{\circ}$, 1997: 19.

${ }^{8}$ R. Launay, Beyond the Stream ..., op. cit.

9 J.G. Prestholdt, "As Artistry Permits and Custom May Ordain: The Social Fabric of Material Consumption in the Swahili World, circa 1450 to 1600", Program of African Studies (PAS) Working Papers 3, Evanston, Northwestern University, 1998, 56 p. 
encroachments of the foreigners. For instance, to Arab claims over Islamic authority and "orthodoxy", coastal Africans juxtaposed their own Arab and Persian descent of the Shirazi ${ }^{10}$. In contrast to other Swahili following patrilineal descent, however, the Shirazis in Mozambique retained matriliny ${ }^{11}$.

On the other hand, the Shirazi identities were also constructed in opposition to Africans of the hinterland portrayed as pagans and uncivilized people of the bush. The Shirazis believed that they had exclusive claims over Islamic identity and authority, and that the coastal soil itself was blessed by Islamic faith and Muslim ancestors ${ }^{12}$.

Local oral traditions maintain that when the Portuguese occupied in the sixteenth century important Swahili towns of Quelimane, Sofala and Mozambique Island, among others, many Shirazis had abandoned the old settlements and founded new ones along the coast, which remained independent from the Portuguese until the beginning of the 20th century. These settlements were then incorporated into the sphere of influence of Angoche Sultanate, the only important Swahili enclave that escaped Portuguese ravages ${ }^{13}$. Angoche also took over the traditional Swahili trade and established political and economic dominance among the Swahili settlements ${ }^{14}$. However, the continuous migration towards the coast of the Marundi and the Zimba or Marave, followed by the Mpamella and Marrevoni, and finally, the Nguni expansions forced the coastal people to reassess their attitudes toward the mainlanders ${ }^{15}$. The migrants approached the seashore at the time when the

${ }^{10}$ R.L. Pouwels, Horn and Crescent: Cultural Change and Traditional Islam in East African Coast, 800-1900, Cambridge, Cambridge University Press, 1987: 32-37, 82-83, 91-94; A. Nimtz Jr., Islam and Politics in East Africa: the Sufi Orders in Tanzania, Minneapolis, Minnesota University Press, 1980: 30, 107-108.

11 See, L.J.K. Bonate, "Matriliny, Islam and Gender in Northern Mozambique", fournal of Religion in Africa (Leiden, Brill), 36 (2), 2006: 139-166.

${ }^{12}$ N.J. Hafkin, "Trade, Society and Politics in Northern Mozambique, 1853-1910", Ph.D. thesis, Boston University, 1973: 33, 36-42, 147, 213, 326.

${ }^{13}$ M. NewitT, "The Early History of the Sultanate of Angoche", Journal of African History (Cambridge, Cambridge University Press), XIII (3), 1972: 402. See also, J. d'Almeida CunhA, Estudo acerca usos e costumes dos Banianes, Bathias, Parses, Mouros, Gentios e Indígenas. Para cumprimento do que dispôs o artigo no 8, 1 do decreto de 18 de Novembro de 1869, Lourenço Marques, Imprensa Nacional, 1885: 43; E.J. de Vilhena, Companhia do Niassa. Relatórios e Memórias sobre os Territórios pelo Governador, Lisbon, Typographia da "A Editora", 1905: 9, 55; E.C. Lupi, Angoche ..., op. cit.: 70, 135, 145, 182; P.M. Aмorim, Relatório ..., op. cit.: 40, 64-65, 100, 115-116; N.J. HAFkin, "Trade ...", op. cit.: 34-35, 51.

${ }^{14}$ F. Elton, Travels and Researches among the Lakes and Mountains of Eastern and Central Africa, Edited and completed by H.B. Cotteril, London, John Murray, 1879: 197-198; Fr. J. dos Santos, Ethiopia Oriental: Descrição das terras da Africa Oriental e dos diferentes povos, animais e aves que habitam, e das conquistas e batalhas gloriosas dos portugueses, Lisbon: Biblioteca dos Clássicos Portugueses, 1891: 258; P.M. Amorim, Relatório ..., op. cit.: 41, 60; E.C. Lupi, Angoche..., op. cit.: 174; J. Capela \& E. Medeiros, O tráfico ..., op. cit:: 96, 105; E.A. Alpers, "Towards a History of the Expansion of Islam in East Africa: the Matrilineal Peoples of the Southern Interior", in T. Ranger \& I.N. Kimambo, eds, The Historical Study of African Religion, London-Nairobi-Ibadan, Heinemann, 1972: 187.

15 E.C. Lupi, Angoche ..., op. cit.: 121-128, 173; P.M. Amorim, Relatório ..., op. cit.: 55; N.J. Hafkin, "Trade ...", op. cit.: 10-26, 211, 339; J.F. Mbwiliza, A History of Commodity Production in 
international slave trade reached its height at the second half of the nineteenthcentury. Both the advent of the new-comers and the slave trade precipitated a significant expansion of Islam into the mainland.

\section{Slave Trade and the Expansion of Islam into the Mainland}

The growing demand for slaves had offered an exceptional and relatively quick chance to accrue wealth for ports such as Angoche, whose chances increased considerably due to the European anti-slave trade abolitionist movement ${ }^{16}$. By the mid-nineteenth century, some of the Shirazi ruling elite of Angoche, the Anhapakho clan, took steps to seize the opportunity of capturing and selling slaves themselves under the leadership of Musa Mohammad Sahib Quanto (d. 1879) ${ }^{17}$. They decided to bring the mainland under the aegis of Angoche. Musa pursued successful military operations, as well as built up a web of allies through kinship relations with important mainland chiefs that facilitated peaceful passage of caravans from the interior to the coast $^{18}$. The web of these paramount chiefs and their subordinates made up the bulk of slave raiders, who established the limits between themselves (the Maca, Muslims and "civilized") and those to be enslaved (the Makhwa and Lomwe, derogatory terms, meaning savagery, i.e., "non-Muslims" and "uncivilized"), and their respective territories ${ }^{19}$.

Makuani, 1600-1900: Mercantilist Accumulation to Imperialist Domination, Dar es-Salaam, Dar es-Salaam University Press, 1991: 128; M. NewitT, A History of Mozambique, London, Hurst \& C. 1995: 75-76.

${ }^{16}$ In 1815, the Vienna Treaty between Portugal and Great Britain on the gradual abolition of slave trade was signed. With the 1836 Sá Bandeira Decree, followed by the Decree of 1842 prohibiting the exportation of slaves, the ports of Mozambique Island and Quelimane from where slaves were exported earlier, became difficult destinations for slave traders (negreiros in Portuguese). See, J.J.T. Botelho, História militar e política dos portugueses em Moçambique de 1833 aos nossos dias, Lisbon, Centro Tip. Colonial, 1936 (2nd ed.): 157-165; J. CAPELA, O escravismo colonial em Moçambique, Porto, Edições Afrontamento, 1993: 23-35 ("As Armas e Varões", 12); R. PÉLissier, História de Moçambique: Formação e Oposição, 1854-1928, translated by Manuel Ruas, Lisbon, Editorial Estampa Lda., 2000, 2 vols, vol. 1: 52, 57-58, 158-60; E. Medeiros, As Etapas Da Escravatura No Norte De Moçambique, Maputo, Arquivo Histórico de Moçambique, 80 p., 1988: 27 ("Col. Estudos", 4); L.J.K. Bonate, "The Ascendance of Angoche: the Politics of Kinship and Territory in Nineteenth Century Northern Mozambique", Lusotopie (Paris, Karthala), 2003: 115-140.

${ }^{17}$ E.C. LuPI, Angoche ..., op. cit.: 174, 182-198; E.C. LuPI, Escola de Mousinho. Episódios de Serviço, Moçambique 1895-1910, Lisbon, Imprensa Lucas, 1912: 33-67; P.M. АмоRiм, Relatório ..., op. cit.: 4-5; J. de Azevedo Coutinho, As duas conquistas ..., op. cit.: 10-31; J.T. Bотеlho, História ..., op. cit:: 232-39; N.J. Hafkin, "Trade ...", op. cit.: 288-319; J.F. Mbwiliza, A History ..., op. cit.: 124127; R. PÉlissier, História de ..., op. cit.: 95, 221-222.

${ }^{18} \mathrm{~J}$. de Azevedo Coutinho, Memórias de um velho marinheiro e soldado de África, Lisbon, Livraria Bertrand, 1941: 31-32; N.J. HAfkin, "Trade ...", op. cit.: 40, 145-147, 213, 315, 326; L.J.K. Bonate, "The Ascendance ...", op. cit.; L.J.K. Bonate, "From Shirazi into Monhé: Angoche and the Mainland in the Context of the Nineteenth Century Slave Trade of Northern Mozambique", in E.A. Alpers, A. Isaacman \& B. Zimba, eds, Slave Routes and Oral Tradition in Southeastern Africa, Maputo, Filsom Entertainment Lda., 2005: 195-219.

${ }^{19}$ J. d'Almeida CunHa, Estudo ..., op. cit.: 43, 46; E.C. Lupi, Angoche ..., op. cit.: 70, 106, 178-179; J. de Azevedo Coutinho, Memórias ..., op. cit.: 31-32; N.J. Hafkin, "Trade ...", op. cit.: 36, 82; 
Musa Quanto's own upbringing and religious outlook might have added some strength for the spread of Islam, because apparently he had a solid Islamic education and knowledge through his association with a zealously religious sharif uncle and his travels around the most important Islamic centres of the East African $\operatorname{coast}^{20}$. However, Musa's main objective was to gain control over the slave trade by creating networks throughout the region, and his projects impacted on the "ethnic" and territorial transformations already underway ${ }^{21}$.

Nevertheless, Musa's conquests fundamentally altered local perceptions of Islamic identity, because they allowed mainland Africans to adopt Islam too. The mainlanders were given an option of conversion in order to escape enslavement. As a result, Islam was not anymore associated only with the coastal Shirazi Swahili clans, but became an inclusive and broader faith of all Muslims identified as Maca. However, the Islamic authority remained attached to ruling elites, such as Shirazis at the coast and the chiefs of the mainland, whose power and legitimacy rested above all on the premise that they were the lords of the lands (the muyini/mwene/monhé) and Muslim rulers, the washehe (Sw., pl., sing., shehe, from Ar. shaykh)22. Because the mainland chiefs remained the lords of the lands with matrilineal heritage, the conversion to Islam did not alter matrilineal ideology among them ${ }^{23}$.

Nevertheless, Islam continued to be conceived in line with the regional Swahili tradition. For example, because of the link between the chiefly lineage and the spiritual world of land and ancestors, Islam became, as Randall L. Pouwelss puts it, a "walimu style of Islam"24. This meant that on the conversion to Islam, the healers (mkulukwana) of the mainland chiefs turned into mwalimo in the fashion of the Swahili at the coast. They continued to fulfill functions of the mkulukwana, such as of the guardians of spiritual and ritual knowledge, and experts in local genealogical histories and physical environment, whose main purpose was to deal

J. Capela \& E. Medeiros, O tráfic ..., op. cit.: 97-98; M. Branquinho, "Relatório ...", op. cit.: 306. D. ReIs, "Os Macuas do Mogovollas", Boletim da Sociedade de Estudos de Moçambique, XXXI (131), 1962: 35.

${ }^{20}$ According to Portuguese sources, Musa had traveled and learned extensively during his teens while accompanying his uncle, an Islamic proselytizer, a haji (a pilgrim to Holy Mecca) and a sharif (descendant of the Prophet Muhammad). Together they went to Zanzibar, Madagascar, the Comoros and to the Mozambican interior along the Rivers Zambezi and Lugenda. It seems that during these journeys Musa conceived of the project of Angoche's expansion into the interior which with the widespread circulation of firearms and increasing armies of slave sepoys, became possible. Hafkin even suggests that one of the objectives of Musa's military operations was proselytizing Islam among the people of the interior, and that he pursued a campaign of a purifying holy war (jïhad). N.J. HAFkin, "Trade ...", op. cit:: 336-337.

${ }^{21}$ E.C. Lupi, Angoche ..., op. cit.: 129, 134; P.M. Aмorim, Relatório ..., op. cit.: 22-23; A Manual of Portuguese East Africa, compiled by the Geographical Section of the Naval Intelligence Division, Naval Staff, Admiralty, London: Published by His Majesty's Stationary Office, 1920: 96.

${ }^{22}$ E.C. Lupi, Angoche ..., op. cit:: 129; F. Elton, Travels ..., op. cit.: 216.

${ }^{23}$ E.J. de Vilhena, Companhia ..., op. cit.: 56; J. d'Almeida Cunha, Estudo ..., op. cit.: 47; F.A. da S. Neves, Informações á cerca da Capitania-Mór de Angoche, Lourenço Marques, Imprensa Nacional, 1901: 13, 102-103; E.C. LuPI, Angoche ..., op. cit:: 144-145; P.M. АмоRIm, Relatório ..., op. cit:: 100, 102-104; L.J.K. Bonate, "Matriliny ...", op. cit.

${ }^{24}$ R.L. Pouwels, Horn and Crescent ..., op. cit:: 95. 
with the spiritual world and provide for protection and prosperity of the people and the land ${ }^{25}$. But the mwalimo also gained access to the one derived from the kitabu ("the book" in local vernacular, i.e., the Qur'an) in addition to the old local African magic ${ }^{26}$. With these changes, Islam strengthened the power and authority of the chiefs, because not only it opened the gates to the wealth derived from the slave trade, but also introduced new type of mighty magic derived from the Qur'an ${ }^{27}$.

Besides functions of the mkulukwana, associated with the chiefly authority, the mwalimo also served as clerks and scribes for local rulers, and as accountants in commercial dealings, especially while accompanying trade caravans ${ }^{28}$. The Portuguese conquerors reported that the mwalimo led mosque prayers, and rituals related to farming and Islamic calendar dates as well as life cycle ceremonies such as birth, marriage, and death ${ }^{29}$. The mwalimo was also responsible for Islamic education ${ }^{30}$. By the second half of the nineteenth century, literacy in Arabic was widespread among the chiefly elites and even women, who were corresponding with each other in Swahili or in local languages using Arabic script ${ }^{31}$.

\section{Sreahili Islam and the Ritual Arena}

According to Portuguese sources, all Muslim religious rituals were accompanied by collective dancing, feasting and drumming. It was also common to beat and dance drums and feast on funerals, and if a deceased was a chief, then the feast also took place on the third, eighth or tenth, and the fortieth day after funeral ${ }^{32}$. Because of the importance of dancing and drumming in local Muslim life, numerous dance societies existed both at the coast and the mainland". One of the "dance societies" was the Rifa'iyya Sufi Order, which is called in Mozambique Molidi,

${ }^{25}$ F.A. da S. Neves, Informações ..., op. cit.: 13-18; P.M. Амorim, Relatório ..., op. cit.: 94-95, 98, 101-102; M. Branquinho, "Relatório ...", op. cit.: 338; D. Reis, "Os Macuas ...", op. cit.: 35; A. J. de Mello Machado, Entre Macuas ..., op. cit.: 281-282; N.J. Hafkin, "Trade ...", op. cit.: 82; R.L. Pouwels, Horn and Crescent ..., op. cit.: 86-95.

${ }^{26}$ J.M. de Albuquerque, A Campanha contra os Namarrais. Relatórios, Lisbon, Imprensa Nacional, 1897: 11; F.A. da S. Neves, Informações ..., op. cit.: 14-15; P.M. АмоRim, Relatório ..., op. cit.: 95.

${ }^{27}$ F.A. da S. Neves, Informações ..., op. cit.: 14-15; P.M. АмоRim, Relatório ..., op. cit.: 94-102; M. Branquinho, Relatório ..., op. cit:: 338.

${ }^{28}$ J. d'Almeida Cunha, Estudo ..., op. cit.: 48; E.A. Alpers, "Towards a History ...", op. cit.: $185,187$.

${ }^{29}$ F.A. da S. Neves, Informações, op. cit.: 10, 11, 13-14; P.M. АмоRiм, Relatório ..., op. cit.: $113,125$.

${ }^{30}$ J. de Azevedo Coutinho, Memórias ..., op. cit.: 67; F.A. da S. Neves, Informações ..., op. cit.: 17.

${ }^{31}$ J. d'Almeida Cunha, Estudo ..., op. cit.: 48; D. Grove, "O Macua. África Oriental Portuguesa", Boletim da Sociedade de Geografia de Lisboa, XVI, série 2, 1897: 127-145, 139; F.A. da S. Neves, Informações ..., op. cit.: 17; E.J. de Vilhena, Companhia ..., op. cit.: 56; E.C. Lupi, Angoche ..., op. cit:: 152, 176; N.J. Hafkin, "Trade ...", op. cit.: 47; J.F. Mbwiliza, A History ..., op. cit.: 73; E.A. Alpers, "Towards a History ...", op. cit.: 189.

${ }^{32}$ F.A. da S. Neves, Informações ..., op. cit.: 10; F. Elton, Travels ..., op. cit.: 297; J. d'Almeida Cunha, Estudo ..., op. cit.: 48; Neves, Informações ..., op. cit.: 13; E.C. Lupi, Angoche ..., op. cit.: 88; P.M. AMORim, Relatório ..., op. cit.: 124.

${ }^{33}$ E.C. LupI, Angoche ..., op. cit: 106-107, mentions the abundance of dance societies both at the coast and the mainland. 
Mawlid, or Mawlid Naquira (from Emakhwa, "the dancing mawlid"), as well as Mawlid Rifa'i.

Very little is known about the Rifa'iyya in Mozambique ${ }^{34}$. Nancy J. Hafkin, Frederic Mbwiliza and Edwards A. Alpers do not mention it. Local Muslims during fieldwork indicated that the Rifa'iyya had existed before the arrival of the Shadhiliyya and the Qadiriyya ${ }^{35}$. In the Comoro and Zanzibar, the Rifa'iyya had also preceded the advent of the Shadhiliyya and the Qadiriyya ${ }^{36}$. As the northern Mozambique had close ties with these regions, we can assume that the Rifa'iyya had expanded to Mozambique at approximately the same period as in these regions. In 1887, João de Azevedo Coutinho had witnessed a drumming festival near Fernão Velozo or Mogincual, which was performed during "special occasions of the lunar calendar" (i.e., most likely the mawlid) ${ }^{37}$. His description matches a Rifa'i dhikr. Later, António Enes, who was in Mozambique in 1891-92 and 1895, recounted the Rifa'i dhikr performed for him in Mossuril, which he called "drumming dance with knifes", referring to the use of dabbus (Ar., needle) in the Rifa'i dhikr ${ }^{38}$. Although Eduardo do Couto Lupi did not find any evidence attesting to the existence of the Rifa'i 'dance' in Angoche, fieldwork informants believed that Rifa'iyya came first to Angoche and expanded from there to the rest of Mozambique $^{39}$.

August Nimtz Jr points out that by the second half of the nineteenth century, the Rifa'iyya was present not only on the coast but also in the mainland of Tanzania $^{40}$. In Mozambique it seems that the Rifa'iyya $d h i k r$ was practiced by Muslim chiefs, involved in long distance slave trading networks, as well as by the sepoys (slave armies) under their command organized into caravans ${ }^{41}$.

${ }^{34}$ In 1901, J. and M. Lazarus had depicted in a photo album a group of the Mafalala Muslim men dressed in kanzu and performing a dance that looks like a mawlidi ya hom of Zanzibar. In 1955 José Craiveirinha, and later, in the 1970s, Alexandre de Lemos described the mawlid Rifa'i dhikr in the Mafalala zone of the Maputo city, inhabited by the immigrant Makuas. The J. and M. Lazarus's photo entitled "The Mafalala Kafir Dance" was first printed in J. Lazarus \& M. LAzArus, A Souvenir of Lourenço Marques, Lourenço Marques, 1901; See also, M.J. Correia de Lemos, "Reviver a Ilha, na Mafalala", Arquivo (Maputo, Arquivo Histórico de Moçambique), 4, 1988: 49-59.

${ }^{35}$ Hafkin and Mbwiliza hypothesizing about the pre-eminence of the Qadiriyya and the Shadhiliyya Sufi Orders during the eighteenth and nineteenth centuries does not seem to be correct as the evidence suggests that these two Orders came to Mozambique for the first time only in 1897 and 1905. N.J. Hafkin, "Trade ...", op. cit:: 43-44; J.F. Mbwiliza, A History ..., op. cit:: 72; Interview with Shaykh Faqui Sayyid Shamakhani, November 2, 1999, Mozambique Island.

${ }^{36}$ J.S. Trimingham, Islam in East Africa, Oxford Clarenton Press, 1964: 101; A. Nimtz Jr., Islam and Politics ..., op. cit:: 62.

${ }^{37} \mathrm{~J}$. de Azevedo Coutrnho, Memórias ..., op. cit:: 67.

${ }^{38}$ A. Enes, "De Lisboa a Moçambique", Serões, (Lisbon, Administração e Officinas), 1902, 2, chap. VIII: 87-93.

${ }^{39}$ E.C. LupI, Angoche ..., op. cit.: 108. Interviews with Hasan Bashir, the ruling Nhapakho, May 14, 2000; Shaykh Adamji Karhila, May 14, 2000, and Sayyid Hasan, May 14, 2000, all in Catamoyo Island, Angoche District.

${ }^{40}$ A. Nimtz Jr., Ibid.

${ }^{41}$ L.J.K. Bonate, "The Ascendance of Angoche ...", op. cit.: 130. 
An interesting feature of the Rifa'iyya in Mozambique is that it is called Mawlid (Molidi) which also demonstrates how close northern Mozambique was to other Swahili societies in terms of culture, because for example, the Rifa'iyya in Zanzibar, is called maulidi ya hom ${ }^{42}$. Currently, the mawlid ceremony in Mozambique is known as "the Brazanji", which is associated with the Shadhiliyya Yashrutiyya and the Qadiriyya Sufi Orders. Probably prior to the arrival of these two Orders, the mawlid celebration was dominated by the flamboyant and noisy dhikr of the Rifa'iyya, and for that reason it retained the name of mawlid. If it was the case, then the Rifa'iyya dhikr had probably once constituted the mawlid, "the centre" of Islam in Mozambique, in Eva E. Rosander's terms, because mawlid ceremonies were and still are central to the lives of Muslims in northern Mozambique ${ }^{43}$. The ritual dances related to mawlid were probably also the precursors of the modern day Tufo dance, which Lutero and Pereira maintain was performed during the celebrations of the mawlid". Mozambican "Tufo" performance resembles somehow the molidi ya hom of Zanzibar ${ }^{45}$.

\section{The Advent of the New Sufi Orders}

Up to the early twentieth century, the attempts to consolidate the Portuguese sovereignty in this region were futile. At the turn of the century, the Portuguese conducted systematic and well-organized operations of "effective occupation" of its

${ }^{42}$ J.S. Trimingham, Islam in ..., op. cit.: 101; A. Nimtz Jr., Islam and Politics ..., op. cit.: 62.

${ }^{43}$ E. Evers Rosander, "Introduction: The Islamization ...", op. cit.: 19; the importance of mawlid was confirmed by fieldwork observations in Angoche, Mozambique Island and Nampula City in 1999-2000. On the importance of the mawlid in Zanzibar, see in C.C. KIm, "Supernaturalism in Swahili Islam: With special reference to the therapeutic cults of jinn possession", Ph.D. thesis in Philosophy, Pasadena, Fuller Theological Seminary, 2001: 88-89.

${ }^{44}$ The Mozambican Tufo is derived from Swahili Dufu, associated with is a large diameter frame drum, usually round, and made of wood and animal skin, with no jingles used to provide bass rhythm accompaniment. The smaller version of dufu is called $\mathrm{d} /$ taira and is played mainly by women. Iranian Musician, Peyman Nasehpour maintains that Daff, Deff and Taf (the ancient name is Tof), is the Arabicized version of the Persian Dap (Pahlavi, pre-Islamic Persian). It was used in Islamic Persia and other Muslim countries in Kangan (temple of dervishes) during the $d h i k r$ ritual; in <http://donbak.co.uk/Articles/DafTheSpiritualFrameDrum.htm>, last accessed January 14, 2006. M. Lutero and M. Pereira wrote a short chapter about Arabic influences on Mozambican traditional music, in M. Lutero \& M. Pereira, "A Influência árabe na música tradicional", in P.R. Soares, ed., Música tradicional em Moçambique, Maputo, Ministério da Educação e Cultura, 1980: 18-24. According to local oral tradition, the Tufo was born on the day of Prophet Muhammad's entrance to Yathrib (Medina) the 1st of Muharram 1st year of Hegira (July 16, 622), when local women greeted him by drumming and singing a qasida in his honour. In Mozambique, it is believed also that the female version of the Tufo is due to that "Aisha", wife of the Prophet, had sang Tufo to the Prophet Muhammad to distract him from his preoccupations. Interview with Shaykh Faqui Sayyid Shamakhani, November 2, 1999, and with Shaykh Abdurrahman Amuri bin Jimba, Mozambique Island, November 2, 1999, Mozambique Island.

${ }^{45}$ J.S. Trimingham, Islam in ..., op. cit.: 92, 101; C.C. Kim, "Supernaturalism ...", op. cit.: 88-89, 90-n.42; A.H. Nimtz, Islam and Politics ..., op. cit: 62. 
African territories due to the pressure and threat from the British and Germans ${ }^{46}$. This caused a general socio-political and economic crisis in northern Mozambique, in particular among Swahili and Muslim chiefs, who saw not only the end of their economic prosperity derived primarily from slave trade, but also a complete loss of their political independence after Portuguese military conquests and the imposition of the colonial administrative and political systems. The crisis caused a rupture of the previously existing structures and created a sense of personal and collective uncertainties. It was into this environment that the Shadhiliyya and the Qadiriyya Sufi Orders had arrived in 1896 and 1905 respectively ${ }^{47}$. Thus, in Mozambique, as elsewhere, the crisis of power aggravated by economic and social crisis impacted on the emergence of charisma and of the new Sufi Orders ${ }^{48}$.

These Sufi Orders were brought to Mozambique Island following traditional Swahili links, at approximately the same time as in other parts of the East African coast and practically by the same people. First came Shadhiliyya Yashrutiyya in 1897 when Sayyid Muhammad Ma’rouf bin Shaykh Ahmad ibn Abu Bakr (18531905) of the Comoro Islands, the founder of the Order in East Africa, visited Mozambique Island ${ }^{49}$. The Qadiriyya was reportedly brought also first to Mozambique Island in 1905 by a certain shaykh 'Isa bin Ahmad, originally from the Comoros who lived most of his life in Zanzibar" ${ }^{50}$. It is possible that this 'Isa bin Ahmad and the one mentioned by B. G. Martin and Nimtz are the same person, namely 'Isa bin Ahmad al-Ngaziji (also, al-Msujini), who was a khalifa (Ar., sing., deputy, delegate; pl., khulafah) of shaykh 'Umar Uways bin Muhammad al-Barawi (1847-1909), the leader of the Qadiriyya in East Africa ${ }^{51}$.

The Orders first arrived at Mozambique Island probably because the rest of northern Mozambique continued to resist Portuguese colonialism at least until 1918, and thus remained politically unstable. Although the whole of the contemporary Mozambican territory was under the colonial pressure, Mozambique Island was undergoing particularly hard times. It had been in decline since the mid-nineteenth century because it was impeded by the abolitionists to partake in the international slave trade. Its situation aggravated further when it ceased its role as a colonial

${ }^{46}$ Especially, following the 1884-85 Berlin Conference and 1890 Salisbury proposal on the creation of the borders between the Portuguese and British colonies in Africa. The Treaty between Portugal and Lord Salisbury was signed in 1891.

${ }^{47}$ M. Branquinho, "Relatório ...", op. cit:: 352-353, 358; A.P. de Carvalho, "Notas para a história das confrarias Islâmicas na Ilha de Moçambique", Arquivo (Maputo, Arquivo Histórico de Moçambique), 4, 1988: 59-66.

${ }^{48}$ M. Gilsenan, Recognizing Islam: Religion and Society in the Modern Arab World, New York, Pantheon Books, 1982: 28-30; F. Constantin, "Charisma and the Crisis of Power in East African Islam", in D.B. Cruise O'Brien \& C. Coulon, eds, Charisma and Brotherhood in African Islam, Oxford, Clarendon Press, 1988: 67-90; D.F. Eickelman \& J. Piscatori, Muslim Politics ..., op. cit:: 57-60.

${ }^{49}$ J.S. Trimingham, Islam in ..., op. cit.: 98; B.G. Martin, Muslim Brotherhoods in Nineteenth Century Africa, Cambridge, Cambridge University Press: 152-155; A.H. Nimtz, Islam and Politics ..., op. cit:: 60 .

${ }^{50}$ M. Branquinho, "Relatório ...", op. cit.: 358; A.P. de Carvalho, "Notas para ...", op. cit.: 61.

${ }^{51}$ M. Branquinho, "Relatório ...", op. cit.: 353-54; B.G. Martin, Muslim Brotherhoods ..., op. cit:: 157-159; A.H. Nimtz, Islam and Politics ..., op. cit.: 57, 202-n.10; Pouwels, Horn and Crescent ..., op. cit:: 159; A.P. de Carvalho, "Notas para ...", op. cit.: 63. 
capital in 1896, when the Portuguese settlement of Lourenço Marques in the south was proclaimed a capital of Mozambique. At the same time, the Island stopped benefiting from the international trade because Portuguese colonial economic interests were redirected towards South African networks ${ }^{52}$. On top of all that, Portuguese administration had moved out from the Island and the control of the settling of the mainlanders was no longer restricted.

\section{Sufi Orders and Islamic Authority}

At the end of the nineteenth century, Swahili conceptions of Islam with regard religious authority remained unchallenged. When the Shadhiliyya Yashrutiyya came to the Island in 1897, its first converts were local Swahili and Muslim chiefs of Mossuril, Angoche and Mozambique Island, occupying the position of the chief khalifa (sajada khadima) of the Order in their respective territories. Thus, the Order's khalifa-ship came to foment the religious authority of Muslim chiefs further. On the departure of shaykh Ma'arouf, however, supreme leadership of the Order was hotly disputed by local khulafah and a new-comer to the Island, 'Amir bin Jimba of Comoros ${ }^{53}$. Sayyid Ma'arouf's brother, 'Ali and other Comorian khulafah were dispatched to Mozambique Island to settle the disputes, but 'Amur bin Jimba was accepted as the chief khalifa of the Order only after residing on the Islands for approximately ten years, marrying into local Swahili family of the Comorian/Hadrami descent and bearing four offspring. In general, the leadership of the Yashrutiyya remained in the hands of the Muslim chiefly elites until 1936.

This was not the case with the Qadiriyya, which though arrived along the traditional Swahili routes and links, in fact had its first converts among the "Moors" of the Cabaceira Pequena (the mainland of Mozambique Island) ${ }^{54}$. According to Shaykh Abdurrahman 'Amuri, the only surviving son of 'Amur bin Jimba at the time of fieldwork, when Shaykh 'Isa came to the Island in 1905, he was informed about the existence of the Yashrutiyya, but 'Amur bin Jimba was performing häj ${ }^{55}$.

52 A. Lobato, "Ilha de Moçambique: Noticia Histórica", Arquivo (Maputo, Arquivo Histórico de Moçambique), 4, 1988: 67-78: 73-75; A. Sopa, "Campos Oliveira: Jornalista e Escritor Moçambicano", Arquivo (Maputo, Arquivo Histórico de Moçambique), 4, 1988: 105-147, 113-115; M.J.C. de Lemos, "Reviver a Ilha ...", op. cit.: 50.

${ }_{53}$ M. Branquinho, "Relatório ...", op. cit:: 353-358; A.P. de Garvalho, "Notas para ...", op. cit: $61-63$.

${ }^{54}$ I am using here the pre-colonial Portuguese term "Moors", applied to Muslims in general, but specifically in Mozambique Island to Indian Muslims (from Daman in Gujarat), or the offspring of Indian men and African women, for the lack of a suitable term. Cabaceira Pequena is the region, were historically Indian Muslims and the "Moor" community held their landedestates and for the most times, resided too. I am differentiating the category of "Moors" from the Portuguese term monhé, applied to Muslim Indians or people of Indian descent during the twentieth century, because at the turn of the century this term was still applied to Swahili and African Muslim chiefs, for which see, Bonate "From Shirazi into Monhé", op. cit. I am also differentiating the "Moors" from the later Indian and Pakistani who were incorporated into their own associations of the Comunidades Maometanos or Comunidades Muçulmanos.

${ }^{55}$ Interview with Shaykh Abdurrahman Amuri bin Jimba, Mozambique Island, November 2, 1999. 
Shaykh 'Isa did not launch the Qadiriyya on the Island at once but decided to wait for 'Amur bin Jimba's return out of respect. Instead he traveled to Cabaceira Pequena, where he initiated the Order's first adepts, who turned out to be mostly "Moors". This fact had paved the way for the ensuing competition over the leadership of the Order between "Moors" and African Muslim chiefly clans.

Until the beginning of the twentieth century, religious authority of the Swahili and Muslim chiefs was rarely contested. "Moors", on the other hand, lived in the Portuguese-controlled lands, such as Cabeceiras, Mossuril and Mozambique Island, as wells as in Quelimane, Sofala and Inhambane. Islamic authority within the "Moor" community remained among their own, but it probably had an insignificant, if any, bearings on African Muslims. When the Portuguese moved the colonial administration away from Mozambique Island, the "Moors" found themselves not only suddenly immersed in a massive landscape dominated by the powerful Muslim chiefs, but also outside the colonial patronage. In this context, the adherence to the Qadiriyya offered to them opportunity for laying claims on Islamic authority in equal footing with Africans, and Momad Arune, a Cabaceiran "Moor", became the chief khalifa of the Qadiriyya on shaykh 'Isa's departure in 1925.

Despite that the first converts of the new Orders were Muslim chiefs, Sufi doctrinal conception of authority clashed with the old Islamic authority linked to the chiefly power of the lords of lands associated with matriliny. The Orders established the authority of learning, centred on written Islamic sources and written ijaza (Ar., a document that situates the Order within a chain of transmission, silsila/isnad, proving the authenticity of the Order and legitimacy of its khalifas), which posed serious challenges to the old conception of Islam ${ }^{56}$. The search and obtaining of a stronger, and therefore, more legitimate silsila from the 'centres' of Islam abroad became one of the means to overcome rivalry and competition over authority. One of the important examples with this regard is the reversion of the Qadiriyya leadership from the "Moors" to the local chiefly clans, in particular to Sayyid Abahasan Abdurrahman, a descendant of the Swahili rulers of the Sancul Shaykhdom in Mossuril, whose father was a Comorian Hadrami sharif. He became the Qadiri chief khalifa upon the death of Momade Arune in 1929. In order to contravene the "Moorish" claims to the Order's leadership, Sayyid Abahasan obtained a silsila from Sayyid 'Umar ibn al-Qullatain of Zanzibar, the leader of the Qadiriyya in East Africa at that time. The silsila was read at a ziyara gathering at the Central mosque of the Mozambique Island ${ }^{57}$. Though Sayyid Abahasan was accepted as the chief khalifa of the Qadiriyya, his visit to Cabaceira Pequena in the following year (1930) stirred up such a controversy among Muslims that the Portuguese had to dispatch a military regiment and arrested twenty six people, while more than a hundred were called for depositions during the following trial ${ }^{58}$.

Among African Muslims themselves, the contest between the old conceptions of Islamic authority and Sufi doctrine continued. As a consequence, many Muslims

\footnotetext{
${ }^{56}$ A. BANG, "Islamic Reform ...", op. cit:: 18-20, 28-29, 32.

${ }^{57}$ M. Branquinho, "Relatório ...", op. cit.: 354; Shaykh Ba Hasan is listed in Zanzibar among the important Qadiri khalifas of Sayyid 'Umar al-Qullatain. Courtesy of Mwalimo Idris (M. Idris M. Saleh), Stone Town, Zanzibar, September 26, 2004.

${ }^{58}$ M. Branquinho, "Relatório ...", op. cit:: 356.
} 
from prominent families came to see chiefly and Islamic authorities to be incompatible and opted to renounce the Orders' khalifa-ship on taking up the position of a lineage chief. Such was the case, for example, of Abdul Kamal Megama ${ }^{59}$.

\section{Sufi Orders and Religious Ritual}

Sufi Orders brought new religious books and new qasaid (pl., from Ar., qasida, devotional poetry), the Brazanji collection, all in Arabic, and the madrassas that focused on actual reading and memorizing the Qur'an had multiplied. Dhikr (locally d/tikiri), ziyara and the Brazanji mawlid became central religious rituals replacing the old mawlid accompanied by drumming and dancing. Sufis in Mozambique, similar to other parts of the Swahili world waged a "dufu war" ${ }^{60}$. Most of the new Orders' efforts seem to have been directed against the Rifa'iyya and other ritual dances accompanied by drums. As a consequence of the new Orders' claims, both the Rifa'iyya and the Tufo became relegated to the realm of non-respectable, thus marginal in Rosander's terms. They were not eliminated completely but became a refuge for former slaves and newcomer mainlanders who through these practices could affirm their Islamic identities and secure their masters' patronage ${ }^{61}$.

One of the long-standing debates that originated at this time was dispute over the "correct" performance of Islamic funeral rites. This debate was an extension of the "dufu war", becase drumming during funeral was a common practice before the arrival of the new Sufi Orders ${ }^{62}$. For example, one of the Portuguese colonial officials named Neves mentions that the Shirazi of Angoche at the end of the nineteenth century had great drumming feasts called maffufuni on the fortieth day after the death of the Sultan ${ }^{63}$. With the arrival of the Orders, the funeral drumming was replaced by the performance of dhikr/tiquiri ${ }^{64}$.

The funeral dispute was called sukuti os dikiri (from Ar. sukut, silent, and dhikr, the Sufi chanting) in Mozambique Island and among the Yao and, sukuti vs nashidi in Angoche (from Ar., nashid, clapping hands, being active, or in motion). Alan Thorold points out that the sukuti/sikiri debate was taking place in the Jalasi

${ }_{59}$ B.B. Jỗo, Abdul Kamal e a História de Chiúre nos séculos XIX e XX: um estudo sobre as chefaturas tradicionais, as redes islâmicas e a colonização portuguesa, Maputo, Arquivo Histórico de Moçambique, 2000: 61-62 ("Estudos" 17); E.A. Alpers, "East Central Africa", in N. Levtzion \& R.L. Powuels, eds, The History of Islam in Africa, Athens (Ohio), University Press - Oxford, James Curry - Cape Town, David Philip, 2000: 313.

${ }^{60}$ In Mozambique, the reforms were not specifically against the daff/dufu, but against the use of drums in general in religious ceremonies and in ritual spaces. For other Swahili societies, see J.S. Trimingham, Islam in ..., op. cit.: 82, 98-101; A.H. Nimtz, Islam and Politics ..., op. cit.: 78-81, 137; R.L. Powuels, Horn and Crescent ..., op. cit.: 196-198.

${ }^{61}$ Interviews with Shaykh Muhammad Sandique, November 1, 1999, Shaykh Shaban Muzé, November 2, 1999, and Shaykh Faqui Sayyid Shamakhani, November 2, 1999, Mozambique Island. See also M. Strobel, Muslim Women in Mombasa, 1890-1975, New Haven-London, Yale University Press, 1979: 8-12, 196-216, 157, 164-165; J. Glassman, Feasts and Riot, Revelry, Rebellion, E Popular Consciousness on the Srwahili Coast, 1856-1888, Portsmouth, Heinemann, 1995

${ }^{62}$ P.M. Amorim, Relatório ..., op. cit.: 142.

${ }^{63}$ F.A. da S. Neves, Informações ..., op. cit.: 13.

${ }^{64}$ P.M. Amorim, Relatório ..., op. cit.: 142. 
chiefdom of the Yao in Nyassa region as early as $1937^{65}$. This dispute was so strong that in 1949 the British colonial government invited Sharif Abdul Hasan b. Ahmed Jamali Laili, a respected scholar from Zanzibar, to arbitrate ${ }^{66}$. He held meetings attended by thousands of Mangoshi Yao, but was unable to make them to resolve their differences. Disagreements among Muslims in northern Mozambique were also very acute and required the intervention of the various regional 'ulama, holding the position of a mufti (Ar., an Islamic jurisconsult). In one instance, in 1968, Shaykh Momade Sayde Mujabo of Mozambique Island issued a fatwa determining that the funerals should be celebrated "in a normal voice" as opposed to either shouting or silence ${ }^{67}$. In another case, in 1972, the Portuguese brought Sayyid Omar b. Abu Bakr b. Sumait al-Alawi, the most important Islamic authority of the Comoros at the time, the former the qadi of Zanzibar, whose fatwa favoured the $t /$ dikiri ${ }^{68}$.

\section{Islamism}

First Islamists became known as the Deobandis, when in 1951 Muhammad Cassimo Mahomed Tayob, a "Moor" from southern Mozambique returned after completing his studies in Dar ul-Ulum Seminary in Deoband, India ${ }^{69}$. Overwhelimingly the Deobandis were Dar ul-Ulum graduates, but their influence was felt only in southern Mozambique and they did not engage in direct confrontations with either Swahili or Sufi leaders in northern Mozambique. The Deobandis did not have nation-wide claims for authority and power as the following generations of the Islamists, such as the Wahhabis, had.

The Wahhabi group began emerging from 1960, when Momad Yussuf, a grandson of the prominent Qadiriyya Sadat khalifa at Mozambique Island, Haji Ahmad Haji Yussufo, returned from his studies in Mecca $^{70}$. In 1964, he joined another

${ }^{65}$ A. Thorold, "Metamorphoses of the Yao Muslims", in L. Brenner, ed., Muslim Identities and Social Change in Sub-Saharan Africa, London, Hurst \& C', 1993: 79-91, 85-90.

${ }^{66}$ E.A. Alpers "East Central Africa ...", op. cit:: 313.

${ }^{67}$ F.A. MonteIro, "Sobre a Actuação da corrente 'Wahhabita' no Islão Moçambicano: algumas notas relativas ao período 1966-77", Africana (Porto), Edições de Centro de Estudos Africanos da Universidade Portucalense, 1993, 12: 91; F.A. Monteiro, O Islão, o Poder, e a Guerra: Moçambique 1964-74, Porto, Ed. Universidade Portucalense, 1993: 270-71.

${ }^{68}$ E.A. Alpers, "East Central Africa ...", op. cit.: 303-327.

${ }^{69}$ Administração do Concelho de Lourenço Marques, "Respostas ao questionário a que se refere a nota $n^{\circ} 164$ de 24/2/66 do extinto Gabinete de Zona de Serviço de Acção Psicossocial de Lourenço Marques", in SCCIM, IAN-TT, Lisbon, Cx. 63, n 413, Pt. 1: 352-59.

${ }^{70}$ Administração do Concelho de Lourenço Marques, "Resposta ao questionário a que se refere a nota ${ }^{\circ} 164$ de 24/2/1966 do extinto Gabinete de Zona do Serviço de Acção Psicossocial de Lourenço Marques", in SCAIM, IAN-TT, Lisbon, Cx. 63, n 413, Pt. 1: 336-43. Lourenço Marques, Amaro Monteiro, /1971/Assunto: Evolução do Islamismo nos Distritos de Lourenço Marques, Gaza e Inhambane, in SCCIM, IAN-TT, Lisbon, Cx. 63, n 413, Pt. 2: 533; Grupo de Trabalho sobre Assuntos Islâmicos, "Breve esquemática do pensamento muçulmana, com vista a inserção e caracterização do movimento Wahhabita, 1 de Julho de 1972, o Presidente do Grupo, Dr. Fernando Amaro Monteiro", in Arquivos da PIDE/DGS, Processo 6037 - CI(2) "Unitários ou Wahhabitas", IAN-TT, Lisbon: 14-18. 
recent Saudi graduate, Abdulbacar Musa Ismael "Mangira", who completed a course at the Shari' a Department of the Medina University ${ }^{71}$. Abubacar "Mangira" became an organizing and motivating force for the Deobandi and Saudi graduates, who challenged the old Islamic establishment of northern Mozambique.

What makes Islamism radically different from other conceptions of Islam is in the first place their doctrinal outlook. As elsewhere, Islamism in Mozambique is marked by puritanical scripturalism and tendencies to rationalize religious practices $^{72}$. Islamists, conceive of Islam as an ideology, a total way of life, and demand a literal interpretation of the Islamic sources (the Qur'an and the Hadith) and ubiquitous application of the Sharia (Islamic legal principles), besides denouncing a "blind" imitation of the Western lifestyles by Muslims ${ }^{73}$. Their primary targets in Mozambique, as elsewhere, have been Sufi Orders, with whom they associate such activities as saint veneration and tomb visitation, spirit-possession cults, Islamic medicines and magic, and celebrations of the Prophets' birthday (mawlid), all categorized as jahiliyya (Ar., ignorance), shirk (Ar., polytheism) and bid'a (Ar., abominable religious innovation).

The conflict between Sufi Muslims and the Wahhabis soon escalated into direct confrontations. Following the visit of two eminent Sufi shaykhs from Mozambique Island, Sayyid Mujabo and Sayyid Bakr to Anuaril Islamo mosque in Lourenço Marques, Muslims complained to Portuguese provincial government against Abubacar "Mangira" on December 10, 1971". He had ridiculed the two influential Sufi shaykhs in front of 800-people strong congregation, calling them "ignorants" and proponents of bid'a.

Finally, in August 15, 1971, Sayyid Bakr, the leader of the most widespread tariqa, Qadiriyya Sadat, declared to the Portuguese that he was fed up with the emotional climate in which Muslims were living in due to the controversies surrounding notions of bid $a^{75}$. He threatened to take action against the Wahhabis, or otherwise orchestrate a simultaneous violent uprising in three Districts of northern Mozambique. The Portuguese took him very seriously, and forced to face a choice between Sufis, consisting mostly of northern Mozambican African leadership and the southern "Moor" Wahhabis, they chose to support Sufis. As the independence

${ }^{71}$ F.A. Monteiro, "Sobre a actuação ...", op. cit.: 91-95, 104-105; F.A. Monteiro, O Islão, o poder ..., op. cit:: 413; E.A. Alpers, "Islam in the Service of Colonialism? Portuguese Strategy during the Armed Liberation Struggle in Mozambique", Lusotopie, 1999: 165-184, 181-182; M. CAHEN, "L'État Nouveau et la diversification religieuse au Mozambique, 1930-1974, II-La portugalisation désespérée (1959-1974)", Cahiers d'études africaines, 159, XL (3), 2000: 551-592, 582-583.

${ }^{72}$ L. Brenner, "Muslim Representation of Unity and Difference in the African Discourse", Introduction to L. Brenner, ed., Muslim Identity and Social Changes in Sub-Saharan Africa, London, Hurst \& $C^{\circ}, 1993: 1-21$.

${ }^{73}$ E. Evers Rosander, "Introduction: The Islamization ...", op. cit.: 4-12; D.F. Eickelman \& J. Piscatori, Muslim Politics, op. cit:: 39, 42, 44-45; D. Westerland, "Reaction and Action: Accounting for the Rise of Islamism", in E. Evers Rosander \& D. Westerland, eds, African Islam ..., op cit:: 308-333.

${ }^{74}$ F.A. Monteiro, "Sobre a actuação ...", op. cit.

${ }^{75}$ F.A. Monteiro, "As comunidades islâmicas de Moçambique : mecanismos de comunicação ", Africana (Porto, Universidade Portucalense), 4, 1989: 85. 
war was already underway in northern Mozambique, and Portuguese Secret Services identified Sufi Orders and Sufi shaykhs as holding a significant authority and power in northern Mozambique, they saw this to be the best choice possible ${ }^{76}$. The Portuguese were determined to coopt northern Sufi leadership politically and gain its alliance against the liberation movements. They considered Wahhabis as upholding a globalist and universalist view of Islam with pan-Islamic solidarity, and thus difficult to compromise by an European rule ${ }^{77}$.

But "Mangira" sought a recognition and collaboration from the colonial state. He contrasted himself with the "ignorantC Sufis and portrayed himself as welltrained, more modern and therefore better suited to be a nation-wide Islamic authority associated with the Portuguese rule. He suggested to the Portuguese to organize a "round- table" with Sufi shaykhs, in which once and for all it could be logically and manifestly proved who was wrong and who was right ${ }^{78}$. As Monteiro points out, "Mangira" "insinuated that the leaders of the turuq were incompetent", and were not "prepared or capacitated to make just and correct decisions in the field of Islamic religion"79. To "correct" this alleged situation and knowing that the Portuguese were thinking of sponsoring the Qur'anic education in Portuguese, he suggested opening a "new Islamic college for girls and boys in separate blocks," where Portuguese language and Islamic doctrine in Arabic would be taught" But to no avail. During the last years of colonialism the Portuguese showed public support to Sufis as opposed to the Islamists, such as Abubacar "Mangira". Despite this seemingly apparent collaboration with the colonial rule, Muslim chiefs and Sufi shaykhs in northern Mozambique played important roles in the liberation movements and the war for the independence.

Mozambique gained its independence in 1975 under the leadership of the Frelimo, which was secularist and redefining itself as a Marxist-Leninist political party by 1977. A short period of religious persecutions and banning of the 'traditional structures' followed. However, after two meetings with delegations of the Muslim World League (Rabitat al-Alami al-Islamiyya with headquarter in Saudi Arabia), in 1980 and 1981, the Frelimo reconsidered its positions towards Muslims and decided to create a national Muslim organization ${ }^{81}$. The Islamic Council was established without the participation of the northerners, in a meeting between the government and a group of Maputo imams in January 1981, who elected Abubacar Ismael "Mangira" as the co-coordinator of the Council, later its first national Secretary ${ }^{82}$.

${ }^{76}$ F.A. Monteiro, "Sobre a actuação," op. cit.: 89-94; F.A. MonteIro, O Islão, o poder ..., op. cit:: 303-311; E.A. Alpers, "Islam in the Service ...", op. cit.: 172-173; M. CAhen, "L'État Nouveau ...", op. cit:: 575-577.

77 F.A. MonTeiro, "Sobre a actuação", op. cit.: 89, 90.

${ }^{78}$ Ibid:: 93.

79 Ibid: $93-95$.

${ }^{80}$ F.A. Monteiro, O Islão, o poder ..., op. cit.: 411.

${ }^{81}$ Letter by Dr. M. I. Momoniat, Muslim World League to the President of Mozambique, Mr. Samora Machel, dated August 16, 1983. Archives of the Department of Religious Affairs, Mozambique Ministry of Justice, Maputo (DAR).

${ }^{82}$ É. Morier-Genoud, "L'islam au Mozambique ...", op. cit.: 132-33. 
The government's acceptance of "Mangira" as a head of a national Islamic organization created a sense of unease among Sufis and 'African traditionalist' Muslims, who saw it as denial of their Islamic identity by the government. The northern Mozambican Muslims felt that Frelimo unduly ignored their long-standing Islamic tradition and their sheer numerical advantage over the southern Muslim, when choosing a head of a national Islamic organization. The northerners also viewed unenthusiastically an appointment of a "Moor" for the highest post. However, in 1982, the President Samora Machel recommended confessional groups to be organized into national organizations. With this official permission, Muslims discordant with Islamists created their own national organization in 1983, called the Islamic Congress ${ }^{83}$. Most of the pre-colonial associations and confraternities, including Sufi Orders, became affiliated to the Congress ${ }^{84}$.

The Islamic Council denounced confraternities and associations as incompatible with the spirit of Islam, linking them to the colonial power and "traditional authority" ${ }^{\prime \prime 5}$. It opted to operate through local mosques and Provincial and District delegations $^{86}$. By 1984, the Council established delegations and sub-delegations in almost all of Nampula province, including Mozambique Island, Angoche, Nampula City, Nacala, Memba, Mogincuale, Netia, Monapo and Morrupula ${ }^{87}$.

The Council also established relationships with Africa Muslims Agency of Kuwait, Jamiyya al-Da’wa al-Islamiyya of Lybia, and al-Merkaz of the Sudan, Islamic Development Bank, and received scholarships to the universities of Al-Azhar and Madina, as well as of the Sudan, Libya and Algeria ${ }^{88}$. In particular, religious training at the universities abroad, to which Mozambicans gained access through international Islamic NGOs, has augmented the ranks of the Islamists. Ironically, even when the Congress members accessed scholarships through the World Muslim League or the Africa Muslims Agency, both of which tried to maintain equal relationships with the Congress and the Council, the graduates came back as Islamists and frequently joined the Council instead of the Congress on their return.

\section{Islamism and Islamic Authority}

Islamist conception of a legitimate religious authority is that of the "ulama with "adequate" religious training, though they denounce the "traditional" 'ulama for accommodating to the classical juridical schools (Ar., pl., madhahib), which allegedly resulted in taqlid (Ar., stagnation in religious reasoning), the cause of Muslim "backwardness" and "un-modernity." Islamists call for ïtihad (Ar., independent reasoning), which the "traditional" "ulama allegedly had sealed in the tenth century.

${ }^{83}$ Syntheses of the meeting with the Islamic Congress of Mozambique, Maputo, September 9, 1984, DAR.

${ }^{84}$ Ibid.

${ }^{85}$ Letter from Abubacar "Mangira" dated May 31, 1986, DAR.

${ }^{86}$ Ref $\mathrm{N}^{\circ} 356 / \mathrm{DAR} / \mathrm{MJ} / 83$, DAR.

${ }^{87}$ Report $\mathrm{N}^{\circ}$ 03/84, dated May 16, 1984, DAR.

${ }^{88}$ Refs. 123/SG/84; 142/SG/86; 522/DAR/MJ/1985; 80/SG/1985; 66/SG/1986, DAR. Letter from Abubacar "Mangira" to the Minister of Justice, ref. 56/SG/86, Maputo, dated March 31, 1986, DAR. 
Islamists in Mozambique, as elsewhere, represent themselves as "true" champions of "orthodoxy", entitled to correct the wrongdoings of Muslims. However, the older generation of Islamists lacked both political and social legitimacy in order to impact religious reforms to a great degree. On the one hand, Islam they wished to reform was mostly sited in northern Mozambique where it had deeply rooted tradition lasting for more than a thousand years. On the other, they were mostly comprised of "Moors", i.e., descendants of Indians.

When a crisis within the Islamic Council erupted in 1998 in northern Mozambique, it reflected these perceptions as well as divergent political orientations of the Council's northern members and its southern "Moor" leaders. Twenty four younger affiliates abandoned the organization and created an alternative one called Ansar al-Sunna or Ahl al-Sunna ${ }^{89}$. The schism allegedly resulted from racial discrimination of the Council's leadership towards Africans, because as stated above, Shaykh Abubacr "Mangira" and Shaykh Aminuddin Mohamad Ibrahimo were of mixedrace Indian-African descent, corresponding to the historical group of "Moors" in the north. The new generation of Islamists was mostly comprised of Africans, who felt that despite having a sound religious training from Islamic universities abroad, they were allowed to occupy only subordinate and inferior positions both within the structures of the Council itself and in the institutions it controlled, such as mosques and madrassas. Among other reasons for their withdrawal from the Islamic Council was the Council leaders' alleged closeness to the Frelimo, which was viewed negatively in Nampula Province, where the following of the opposition party, the Renamo is quite strong, especially in Muslim regions.

This crisis also ensued after the older generation Islamists' failed to legitimize important Muslim holidays. In their desperate attempt to gain wider popular legitimacy among Muslims, the older Council leadership helped Muslim parliamentarians to stage up the 1996 "Muslim Holidays' Affair" which proposed a law turning two Muslim festive dates, Id ul-Fitr (the end of the Ramadan) and Id alAdha (the end of Hajj and of ritual sacrifice, the qurban), into public holidays ${ }^{90}$. This prompted a strong reaction from some Christians, though Christmas is a national holiday despite that it has a secular name, a Family Day, a mere façade for religious celebrations. Nevertheless, some opposition parties and jurists insisted that the proposal infringed upon the secular character of the Mozambican state and constitution. In March 1996, the majority of deputies at the Assembly voted in favor of the proposed law. When, after almost a year of debates, the Supreme Council declared it unconstitutional, this became a watershed for the decline of the old Council leadership's authority both in the eyes of the ordinary Muslims and of the Frelimo party.

${ }^{89}$ Interviews with Shaykh Mamade Abdallah, May 11, 2000; Shaykh Mussa Ibrahimo Siraj, May 13, 2000; Shaykh Hasan Ali "Concaco", Angoche city; and Shaykhs Abubacar Hussein and Hussein Cesar, June 19, 2000, Nampula City.

${ }_{90}$ É. Morier-Genoud, "The 1996 'Muslim Holidays' Affair: Religious Competition and State Mediation in Contemporary Mozambique", Journal of Southern African Studies (London, Routledge), XXVI (3), September 2000: 409-427. 


\section{Islamism and the Ritual Arena}

As stated earlier, Islamists have targeted rituals associated with saint veneration, spirit-possession cults, Islamic medicines and magic, and celebrations of the Prophets' birthday (mawlid), which were widely but not exclusively practiced in the north, and which Islamists have categorized as jahiliyya (Ar., ignorance), shirk (Ar., polytheism) and bid'a (Ar., abominable religious innovation).

One of the older generation Islamists, also of African-Indian descent and a graduate of the Medina University, Shaykh Aminuddin Mohamad Ibrahimo, took over the presidency of the Islamic Council as well as of the Mozambican 'Ulama Council (Conselho dos Alimos de Moçambique, created in 1988) on the death of "Mangira" in 2000. Shaykh Aminuddin Mohamad holds a considerable authority despite objections from the north because of his warm, conciliatory and apparent politically aloof personality, and also because he has delegated powers to the younger African Islamists within the Islamic Council. But most importantly, because as a true 'alim and unlike the majority of Muslim leaders in Mozambique, he writes books and articles on Islam. Through his writings it is possible to establish his views on religious authority and ritual in Mozambique. In his 1991 brochure entitled Os Pilares da Fé ("The Pillars of the Faith"), Shaykh Aminuddin ${ }^{91}$ refers to Sufis as munafique (Ar., hypocrites, pp. 28-30), and from page 17 to 36 he criticizes various Sufi and African "traditional" Islamic practices, including mawlid (pp. 34-36) characterizing it as shirk (Ar., polytheism, pp. 23-27), kufr (Ar., unbelievers, pp. 28-31), and bid'a (pp. 32-36). In another book, published in 1993, called A Demolidora dos Prazeres ("The Demolisher of the Pleasures", referring to death), the Shaykh dedicates a whole chapter to what he calls the "traditional" ziyyara (pp. 209-46), besides pages on the ziyyara al-qubr (pp. 141-165) ${ }^{92}$. He points out that asking for the intercession from the deceased is shirk, while having feasts near the tombs is bid'a (pp. 142-43). With regard the sukutildikiri dispute, he maintains that "reciting loudly [thus, performing dhikr] on funerals is bid"a" (pp. 101, 246). In other passages, Shaykh Aminuddin criticizes belief in magical powers of the Qur'an (p. 102) and stresses that the purpose of the Qur'an is rather rational and practical (p. 246). He also condemns in strong words the Swahili ritual of katama or khitima (Ar., Khatm al-Qur'an, "the sealing or closure of the Qur'an"), still a widespread practice in Mozambique, and points out that every Muslim should strive to read Qur'an on his own (pp. 209-10, 220-24).

Fieldwork informants revealed that in the late 1980s, the clashes between Islamists and Sufi or 'Swahili'-oriented Muslims sometimes became violent to such an extent that local mosques were divided between belligerent groups. Also, people avoided praying in the mosques of the opposing groups or going to their funerals. Some such cases were recorded by the Archives of the Department for Religious Affairs (DAR) of the Ministry of Justice. For example, in April 18, 1989, a Muslim association called Confraria Islâmica da Matola, complained to DAR about Idrisse

${ }^{91}$ Shaykh Aminuddin Mohamad, Os Pilares da Fé, Maputo, Conselho Islâmico de Mozambique, 1991.

${ }^{92}$ See, L.J.K. Bonate, "Dispute over Islamic Funeral Rites in Mozambique: A Demolidora dos Prazeres by Shaykh Aminuddin Mohammad", Le Fait Missionnaire, 17, December 2005: 41-59. 
Juma who was performing additional prayers at the mosque following usual prayers by the imam". This was a Sufi ritual. Confronted by Shaykh Abubacar "Mangira", Idrisse Juma explained that he had books (Sw., vitabu, pl. sing., kitabu) proving that this ritual was religiously 'orthodox' and legitimate. When the confrontations became heated, Idrisse pointed out that he would not recognize the superiority of "Mangira's" religious authority because he himself was an 'alim.

In another case, imam of the Associação Afro-Maometana mosque in Maputo, Cassamo Capatia and the mosque congregation got involved in mutual battering and some were arrested by the police ${ }^{94}$. Capatia declared his unwillingness to take part in mawlid ceremonies on the Islamic calendar, stating that mawlid was not as obligatory as five daily prayers. He alleged that five daily prayers and other basic pillars of the Islamic faith were being ignored by the congregation who did not dare to miss a mawlid.

\section{Conclusion}

This paper showed that the diversity of the conceptions of Islam in Mozambique resulted from the historical course of Islam in the region as well as from colonial and post-colonial politics and influences of the regional and trans-national Islam. The paper focused on three different conceptions of Islamic authority and religious ritual and analyzed specific historical contexts within which each of them emerged and confronted one another. First one resulted from the region's involvement in the international slave trade in the nineteenth century that broadened conceptions of Islam both geographically and culturally. Despite that, Islam served to strengthen the authority and power of the ruling elites with whom it ultimately became associated with. As most of the rulers were matrilineal, Islam did not obliterate the ideology of matriliny.

The second period started with the advent of two Sufi Orders, the Shadhiliyya Yashrutiyya and the Qadiriyya, at the turn of the nineteenth century that challenged Islamic authority of the chiefly elite and fought against related to them rituals and practices. The third period began in the early 1970s, with the emergence of the Islamists, graduates of foreign Islamic universities, who have dismissed both "African" Islam and Sufi Orders as "deviations" from "true" Islam, promulgating "abominable religious innovations". The Islamist have more universalistic, transnational outlook, and appear to be 'modern', because they use modern means of training and communication, and tend to have formal employment. However, Islamists faced a considerable resistance from the older African Islamic establishment in northern Mozambique, because, on the one hand, Islam in that region had deeply-rooted tradition of more than millennia. On the other, the proponents of Islam and agents of Islamization in northern Mozambique have historically been local Africans, who actively took part in global and regional Muslim debates

${ }^{93}$ DAR, Officio $n^{\circ}$ 014.CUM/DAR/89.

${ }^{94}$ DAR, Letter from the President of the Associação Afro-Maometana, dated May 31, 1987, exposing what had happened and releasing Capatia from his duties as the mosque imam. 
along centuries. The fact that the first Islamists were "Moors" with little religious legitimacy and authority in northern Mozambique, impeded Islamist efforts for reform and the old Islamic conceptions continued to persist.

March 24, 2006

Liazzat J. K. BONATE

Eduardo Mondlane University (Maputo, Mozambique) and

University of Cape Town (Cape Town, South Africa) 